\title{
Academic librarian salaries
}

\author{
By Mary Jo Lynch
}

Director

ALA Office for Research

\section{Salary data as reported in the CUPA 1986-1987 Administrative Compensation Survey.}

$\mathbf{T}_{\mathrm{b}}$ he College and University Personnel Association (CUPA) has conducted a survey of administrative compensation each year for the past ten years. Selection of surveyed positions is based on an analysis of thosc positions common to most higher education institutions. The $1986-1987$ survey reports on 99 "primary" positions, including "Director, Library Services" and 60 "secondary positions" including "Circulation Librarian," “Acquisitions Librarian," "Technical Services Librarian," "Public Services Librarian," and "Reference Librarian." Considerably more information is provided on the primary positions, for which salaries are summarized for control (i.e public or private), three level.s of program (i.e. university, 4-year college, 2-year college), several ranges of enrollment, and several ranges of budget size. For secondary positions, data are available only for two different types of control and three levels of program. Tables in this article were created manually by selecting data on librarian salaries wherever they appear in the CUPA report. Permission of CUPA to use their data in this way is gratefully acknowledged.

${ }^{1}$ Richard C. Creal, Jan P. Miller, and John M. Toller, 1986-1987 Administrative Compensation Survey (Washington, D.C.: College and University Personnel Association, 1987). Available from CUPA, 11 Dupont Circle, Suite 120, Washington, DC 20036-1250. Price to members $\$ 50$; price to non-members who participated in study $\$ 125$ price to all others $\$ 200$, ISBN-0-910402-27-2.
The 1986-1987 questionnaire was sent to 3,190 higher education institutions on a list provided by the National Center for Education Statistics (now the Center for Education Statistics). A total of 1.609 usable responses were received $-51 \%$ of the institutions surveyed. Salary data shown on tables in the CUPA report and in the accompanying tables indicate the median and the interquartile range for each position. Librarians may find it interesting to examine the report itself in order to compare their salaries with other administrators in the same type of institution.

The introduction to the CUPA report contains a useful description of those statistical concepts:

-The median is the middle value in an array of all salaries for the position; half of the salaries are lower than the median and half are higher. The median is considered a more reliable measure than the mean/average because it minimizes the effect of extremely high and low salaries.

-The first quartile (Q1 in the tables) divides salaries below the median into two 25 pereent segments.

- The third quartile (Q3 in the tables) divides salaries above the median into two 25 percent segments.

-Q1 and Q3, therefore, mark the interquartile range; half of all salaries - the middle 50 percentfall within this range.

This means, for example, that if all library director salaries were arrayed from lowest to highest, 
TABIE 1. Salaries paid to Director, Library Services: Overview

\begin{tabular}{lccrr}
\hline & Med & Q1 & Q3 & N \\
\hline All Institutions & $\$ 37,500$ & $\$ 28,620$ & $\$ 48,294$ & 1,182 \\
Public Institutions & $\$ 42,400$ & $\$ 34,977$ & $\$ 53,935$ & 584 \\
Private Institutions & $\$ 32,000$ & $\$ 25,000$ & $\$ 41,000$ & 597 \\
Private Independent Institutions & $\$ 36,000$ & $\$ 26,600$ & $\$ 46,350$ & 315 \\
Private Religious Institutions & $\$ 28,883$ & $\$ 24,100$ & $\$ 34,800$ & 282 \\
\hline
\end{tabular}

TABLE 2. Salaries paid to Director, Library Services: Universities

\begin{tabular}{lcccr}
\hline \hline & Med & Q1 & Q3 & N \\
\hline $\begin{array}{l}\text { All Universities } \\
\text { Public Universities by Enrollment }\end{array}$ & $\$ 50,000$ & $\$ 40,245$ & $\$ 61,974$ & 382 \\
$\quad$ 4,999 or less & $\$ 40,000$ & $\$ 36,754$ & $\$ 45,000$ & 69 \\
$\quad 5,000$ to 9,999 & $\$ 48,624$ & $\$ 43,908$ & $\$ 53,316$ & 74 \\
$\quad 10,000$ to 19,999 & $\$ 58,440$ & $\$ 53,935$ & $\$ 64,000$ & 71 \\
$\quad 20,000$ or more & $\$ 69,500$ & $\$ 63,936$ & $\$ 78,696$ & 40 \\
Private Universities by Enrollment & & & & \\
$\quad 4,999$ or less & $\$ 38,584$ & $\$ 33,000$ & $\$ 45,795$ & 76 \\
$\quad$ 5,000 or more & $\$ 60,100$ & $\$ 51.700$ & $\$ 71,721$ & 51 \\
Public Universities by Budget Range & & & & \\
$\quad \$ 24,999,999$ or less & $\$ 39,650$ & $\$ 36,081$ & $\$ 44,550$ & 63 \\
$\quad \$ 25,000,000-\$ 49,999,999$ & $\$ 47,335$ & $\$ 41,830$ & $\$ 49,283$ & 56 \\
$\quad \$ 50,000,000-\$ 99,999,999$ & $\$ 55,350$ & $\$ 50,434$ & $\$ 60,000$ & 54 \\
$\quad \$ 100,000,000-\$ 149,999,999$ & $\$ 60,000$ & $\$ 55,400$ & $\$ 63,864$ & 18 \\
$\quad \$ 150,000,000$ or more & $\$ 67,600$ & $\$ 61,500$ & $\$ 76,400$ & 63 \\
Private Universities by Budget Range & $\$ 33,000$ & $\$ 28,404$ & $\$ 39,750$ & 42 \\
$\quad \$ 24,999,999$ or less & $\$ 44,000$ & $\$ 38,400$ & $\$ 50,650$ & 32 \\
$\quad \$ 25,000,000-\$ 49,999,999$ & $\$ 52,817$ & $\$ 46,350$ & $\$ 58,200$ & 22 \\
$\quad \$ 50,000,000-\$ 99,999,999$ & $\$ 54,900$ & $\$ 46,565$ & $\$ 56,500$ & 5 \\
$\quad \$ 100,000,000-\$ 149,999,999$ & $\$ 71,500$ & $\$ 64,250$ & $\$ 85,000$ & 26 \\
$\quad \$ 150,000,000$ or more & & & & \\
\hline
\end{tabular}

TABLE 3. Salaries paid to Director, Lihrary Services: 4-Year Colleges

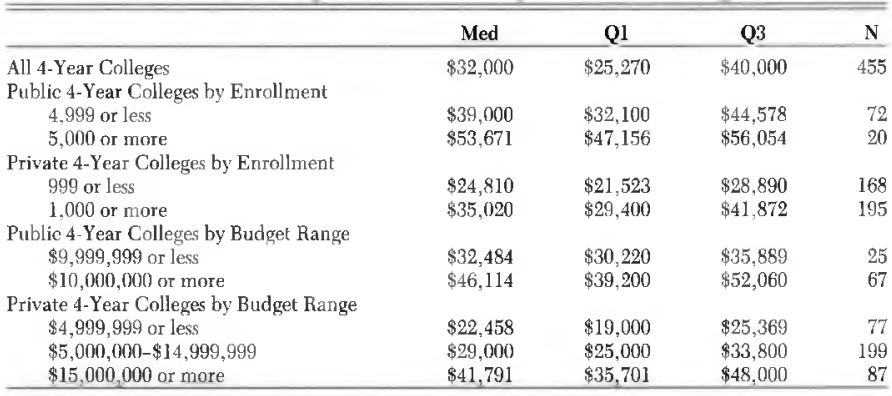

the salary in the middle position, the median, would be $\$ 37,500$ - the first figure shown in the top row on Table 1. Another way of looking at the same array is to note that half of the salaries fall within a range bounded by $\$ 28,620$ - the first quartile (midway between the lowest salary and the median) and $\$ 48,294$ - the third quartile (midway between the median and the highest salary. The quartiles also show that 25 percent of academic library directors earn less than $\$ 28,620$ and 
TABLE 4. Salaries paid to Director, Library Services: 2-Year Colleges

\begin{tabular}{lccrr}
\hline \hline & Med & Q1 & Q3 & N \\
\hline All 2-Year Colleges & $\$ 33,753$ & $\$ 26,933$ & $\$ 39,477$ & 218 \\
All Private 2-Year Colleges & $\$ 23,000$ & $\$ 19,899$ & $\$ 27,480$ & 33 \\
2-Year Technical Institutes & $\$ 30,350$ & $\$ 26,952$ & $\$ 35,640$ & 21 \\
Public 2-Year Colleges by Enrollment & & & & \\
$\quad 999$ or less & $\$ 31,500$ & $\$ 26,874$ & $\$ 35,320$ & 43 \\
$\quad 1,000-2,499$ & $\$ 32,450$ & $\$ 26,078$ & $\$ 38,243$ & 66 \\
$2,500-4,999$ & $\$ 38,885$ & $\$ 35,343$ & $\$ 45,040$ & 39 \\
$\quad 5,000-9,999$ & $\$ 42,106$ & $\$ 36,442$ & $\$ 46,054$ & 23 \\
10,000 or more & $\$ 39,706$ & $\$ 37,838$ & $\$ 49,641$ & $\mathbf{1 4}$ \\
2-Year Colleges by Budget Range & & & & \\
$\quad \$ 4,999,999$ or less & $\$ 27,225$ & $\$ 23,000$ & $\$ 32,200$ & 73 \\
$\quad \$ 5,000,000-\$ 9,999,999$ & $\$ 32,290$ & $\$ 26,600$ & $\$ 36,857$ & 70 \\
$\quad \$ 10,000,000-\$ 14,999,999$ & $\$ 38,885$ & $\$ 34,439$ & $\$ 44,453$ & 26 \\
$\$ 15,000,000$ or more & $\$ 41,631$ & $\$ 36,900$ & $\$ 46,975$ & 49 \\
\hline
\end{tabular}

TABLE 5. Secondary Positions in University Libraries

\begin{tabular}{lccrr}
\hline & Med & Q1 & Q3 & N \\
\hline Circulation Librarian & & & & \\
$\quad$ All Universities & $\$ 25,053$ & $\$ 20,800$ & $\$ 29,376$ & 236 \\
$\quad \begin{array}{l}\text { Public } \\
\quad \text { Private }\end{array}$ & $\$ 25,562$ & $\$ 21,892$ & $\$ 29,675$ & 166 \\
Acquisitions Librarian & $\$ 23,500$ & $\$ 18,540$ & $\$ 28,900$ & 70 \\
$\quad$ All Universities & $\$ 29,238$ & $\$ 24,824$ & $\$ 34,420$ & 258 \\
$\quad \begin{array}{l}\text { Public } \\
\quad \text { Private }\end{array}$ & $\$ 29,455$ & $\$ 26,000$ & $\$ 34,420$ & 187 \\
Technical Services Librarian & $\$ 27,555$ & $\$ 22,580$ & $\$ 33,629$ & 70 \\
$\quad$ All Universities & $\$ 32,868$ & $\$ 26,184$ & $\$ 40,000$ & 254 \\
$\quad \begin{array}{l}\text { Public } \\
\text { Private }\end{array}$ & $\$ 34,104$ & $\$ 28,416$ & $\$ 40,870$ & 168 \\
Public Services Librarian & $\$ 27,514$ & $\$ 21,630$ & $\$ 35,499$ & 85 \\
$\quad$ All Universities & & & & \\
$\quad \begin{array}{l}\text { Public } \\
\text { Private }\end{array}$ & $\$ 34,053$ & $\$ 28,185$ & $\$ 41,130$ & 191 \\
Reference Librarian & $\$ 35,004$ & $\$ 29,000$ & $\$ 42,336$ & 131 \\
$\quad$ All Universities & $\$ 30,650$ & $\$ 25,650$ & $\$ 38,500$ & 49 \\
$\quad \begin{array}{l}\text { Public } \\
\text { Private }\end{array}$ & $\$ 28,518$ & $\$ 23,727$ & $\$ 33,625$ & 297 \\
\hline
\end{tabular}

25 percent earn more than $\$ 48,294$.

It is also important to know that respondents were asked to observe the following specifications in reporting their data: 1986.

- Salaries are those in effect during the Fall of

- Salaries are at an annualized, full-time rate; they reflect only actual cash earnings, excluding any services contributed without charge.

-Enrollment and budget figures are for the operating year 1986-1987.

- Enrollment is stated in terms of equivalent full-time students.

- Budgets include amounts for current education and general operations, including research funds. Budgets do not include amounts for student aid, auxiliary enterprises, service departments, construction, and similar activities.

Definitions of the librarian positions as given on the CUPA survey instrument are as follows:

- Director, Library Services: Directs the activities of all institutional libraries. Functions typically include selection and direction of professional staff, acquisitions, technical services, audiovisual, and special collections.

- Circulation Librarian: Senior person responsible for control of lending and shelving operations.

- Acquisitions Librarian: Senior person responsible for collection development including order and receipt of books, periodicals, etc.

- Technical Services Librarian: Senior person for planning and management of library services involving processing, bibliographic control, cataloging, binding, and repair, etc. 


\begin{tabular}{|c|c|c|c|c|}
\hline & Med & Q1 & Q3 & $\mathbf{N}$ \\
\hline \multicolumn{5}{|c|}{ Circulation Librarian } \\
\hline All Colleges & $\$ 20,441$ & $\$ 15,900$ & $\$ 24,485$ & 154 \\
\hline Public & $\$ 22,809$ & $\$ 19,272$ & $\$ 27,398$ & 38 \\
\hline Private & $\$ 19,740$ & $\$ 15,288$ & $\$ 23,760$ & 116 \\
\hline \multicolumn{5}{|c|}{ Acquisitions Librarian } \\
\hline All Colleges & $\$ 23,300$ & $\$ 19,230$ & $\$ 27,500$ & 157 \\
\hline Public & $\$ 25,358$ & $\$ 21,645$ & $\$ 31,473$ & 52 \\
\hline Private & $\$ 21,331$ & $\$ 18,331$ & $\$ 26,050$ & 105 \\
\hline \multicolumn{5}{|c|}{ Technical Services Librarian } \\
\hline All Colleges & $\$ 23,485$ & $\$ 19,024$ & $\$ 27,848$ & 237 \\
\hline Public & $\$ 28,186$ & $\$ 23,724$ & $\$ 32,448$ & 52 \\
\hline Private & $\$ 22,000$ & $\$ 18,127$ & $\$ 26,064$ & 185 \\
\hline \multicolumn{5}{|c|}{ Public Services Librarian } \\
\hline All Colleges & $\$ 24,357$ & $\$ 19,425$ & $\$ 28,200$ & 129 \\
\hline Public & $\$ 28,192$ & $\$ 24,600$ & $\$ 36,083$ & 35 \\
\hline Private & $\$ 22,256$ & $\$ 18,600$ & $\$ 26,845$ & 94 \\
\hline \multicolumn{5}{|c|}{ Reference Librarian } \\
\hline All Colleges & $\$ 22,475$ & $\$ 19,116$ & $\$ 27,664$ & 240 \\
\hline Public & $\$ 25,764$ & $\$ 21,585$ & $\$ 31,523$ & 59 \\
\hline Private & $\$ 21,500$ & $\$ 18,200$ & $\$ 26,000$ & 181 \\
\hline
\end{tabular}

TABLE 7. Secondary Positions in 2-Year Colleges

\begin{tabular}{lcccc}
\hline \hline & Med & Q1 & Q3 & N \\
\hline $\begin{array}{l}\text { Circulation Librarian } \\
\quad \text { Public }\end{array}$ & $\$ 28,556$ & $\$ 19,000$ & $\$ 34,213$ & 31 \\
$\begin{array}{l}\text { Acquisitions Librarian } \\
\quad \text { Public }\end{array}$ & $\$ 28,221$ & $\$ 22,032$ & $\$ 31,693$ & 35 \\
$\begin{array}{c}\text { Technical Services Librarian } \\
\quad \text { Public }\end{array}$ & $\$ 27,915$ & $\$ 23,227$ & $\$ 34,503$ & 69 \\
$\begin{array}{l}\text { Public Services Librarian } \\
\quad \text { Public }\end{array}$ & $\$ 26,203$ & $\$ 21,000$ & $\$ 33,257$ & 40 \\
$\begin{array}{l}\text { Reference Librarian } \\
\text { Public }\end{array}$ & $\$ 27,063$ & $\$ 23,544$ & $\$ 34,002$ & 64 \\
\hline
\end{tabular}

- Public Services Librarian: Senior person responsible for planning and management of library services involving interaction with patrons (lending, orientation, bibliographic instruction, audiovisual services, etc.).

- Reference Lihrarian: Senior person responsible for developing and managing reference materi-

\section{Humanities programming workshop}

ACRL and the Public Library Association are accepting applications for two additional grantwriting workshops to be held March 23-25, 1988, in Burlingame, California, and October 12-14, 1988, in Chicago, Illinois. The application deadline for the Burlingame workshop is February 19, 1988; the deadline for the Chicago workshop is September 8, 1988. For an application and further information, contact Sandy Donnelly, ACRL, 50 E. Huron St., Chicago, IL 60611-2795; (312) 944-6780. als and assisting users in researching problems, conducting bibliographic searches, etc.

\section{Reach out and teach someone}

In conjunction with the Sixteenth National LOEX Conference held this year at Bowling Green State University in Bowling Green, Ohio, on May 4-6, 1988, abstracts for poster sessions are now being solicited.

The poster sessions must relate to the conference theme, "Reaching and Teaching Diverse Library User Groups," which will focus on adult students, clerical staff, international students, remedial students, and the physically disabled.

The deadline for submitting abstracts is March 1, 1988. For guidelines and forms, write to Janet Pursel, Information Services, Jerome Library, Bowling Green State University, Bowling Green, Ohio 43403; (419) 372-2362. 


\section{Available in 1988 !}

\section{Books for \\ College Libraries, third edition}

With an estimated 50,000 titles in all academic fields of study, chosen by more than 600 American and Canadian college faculty and collection development librarians, the third edition of Books for College Libraries is the most comprehensive and authoritative buying and collection measurement tool available.

Nearly $35 \%$ new material overall assures you that coverage of even rapidly changing fields has been fully updated. In addition to the print version, ACRL and ALA Publishing are researching alternative electronic formats for the BCL3 database that will make automated collection evaluation possible.

Reviews of the second edition:

"The thoroughness of its revision, the careful and authoritative selection of its titles, its excellent indexes, and its full LC card entries all contribute to its importance and usefulness... recommended to all academic libraries as a necessary purchase." Booklist

"...another ALA landmark publication that will help-often rescueanyone who uses it." Library Journal

To receive additional information as it becomes available, please write to: Ruth Ann Jones, Publishing Services/Marketing, American Library Association, 50 East Huron Street, Chicago, IL 60611.

American Library Association • 50 East Huron Street • Chicago, IL 60611 (312) $944-6780$ 